\title{
Education for type 2 diabetes mellitus self-care: from compliance to empowerment*
}

\author{
Antonio Pithon Cyrino ${ }^{1}$ \\ Lilia Blima Schraiber ${ }^{2}$
}

Ricardo Rodrigues Teixeira ${ }^{3}$

CYRINO, A.P.; SCHRAIBER, L.B.; TEIXEIRA, R.R. A Educação para o autocuidado no diabetes mellitus tipo 2: da adesão ao "empoderamento". Interface - Comunic., Saude, Educ., v.13, n.30, p.93-106, jul./set. 2009.

Through a critical review of the literature on education for diabetes self-care and self-management, it was sought to point out the inappropriateness of traditional approaches towards compliance with treatment and transmission of information, considering the complexity of self-care under chronic conditions. The influence of the social sciences on the field of studies on chronic degenerative diseases in general, and diabetes in particular, was explored. From this perspective, it can be recognized that the fields of anthropology and sociology have been incorporated into research focusing more on individuals as patients, and on the experience gained through this process. Recently, there has been a slight change within the field of health education research relating to diabetes, with the introduction of strategies that seek to value the experience and autonomy of patients as self-care agents. This paper discusses the strategy for empowerment in education for diabetes self-care and self-management, as a dialogue-focused practice that respects patients' moral and cognitive autonomy.

Keywords: Type 2 diabetes mellitus. Selfcare. Health education/methods. Chronic degenerative disease. Social sciences.
Em revisão crítica da literatura sobre a educação para o autocuidado e autocontrole no diabetes, procura-se apontar a inadequação das abordagens tradicionais da aderência ao tratamento e da transmissão de informações frente à complexidade do autocuidado em condições de cronicidade. Explora-se a influência das Ciências Sociais sobre o campo de estudo das doenças crônico-degenerativas, em geral, e do diabetes, em particular. Nesta perspectiva, pode-se reconhecer uma incorporação dos campos disciplinares da Antropologia e Sociologia em pesquisas mais orientadas para o indivíduo, em sua condição de portador, e a experiência que desenvolve nesse processo. Há certa inflexão, mais recente, no campo de pesquisas em educação em saúde no diabetes, com a introdução de estratégias que buscam valorizar a experiência e a autonomia dos pacientes como sujeitos de seu cuidado. Neste artigo, discute-se a estratégia do "empoderamento" na educação para o autocuidado e autocontrole no diabetes, como uma modalidade de prática de natureza mais dialógica e de maior respeito à autonomia moral e cognitiva do portador.

Palavras-chave: Diabetes mellitus tipo 2. Autocuidado Educação em saúde/métodos. Doenças crônico-degenerativas. Ciências sociais.
*The study of which this article forms part was funded by The

State of São Paulo Research Foundation (Fapesp) (procedure no. 03/12970-2) and by the UNESP Development Foundation (Fundunesp) (procedure no. 00114/03).

1 Department of Public Health, Botucatu School

of Medicine, Unesp. Distrito de Rubião

Jr. - Cx. Postal: 549 ,

Botucatu, SP, Brazil. 18618-970. acyrino@ gmail.com 2 Department of Preventive Medicine, School of Medicine, USP. ${ }^{3}$ Department of

Preventive Medicine, School of Medicine, USP. 
"Because I know what I'm supposed to do and sometimes we... just don't do it, do we? Because I've been told what I have to do. What I have to avoid to have a better life. What I have to do for my diabetes "not to go up". And sometimes, I overdo things! I don't know if it's when I'm angry... when I'm anxious... Then you look for everything you have... that you can't eat and you go and eat it!"

The interesting excerpt shown above, taken from a statement by a patient with diabetes (Cyrino, 2009), is a clear and explicit expression of the distance that separates knowledge and action in diabetes care. However, only in the 1990s did the international literature on education for diabetes self-care and self-management start to give more emphasis to evidence indicating that simply to pass on information to such individuals is not enough to be able to predict that effective self-care practices will be adopted. In other words, it can be said that although knowledge is a prerequisite, it does not in any way ensure that patients will implement care that results in strict blood glucose control (Snoek, 2002; Coates, Boore, 1996; Bloomgarden, 1987). Thus, exemplifying this point, it needs to be noted that the publication Patient Education and Counseling has highlighted this question in the editorial of a special issue devoted to the topic of diabetes education, with the title: Improving self-management in patients with diabetes: knowledge is not enough (Herbert, Visser, 1996)

This introductory observation draws attention to the hiatus that separates theoreticalmethodological development within the fields of Education and Communication from the approaches that are still adopted in professional practices aimed at diabetes education. In the educational strategies in daily use in care services, prescriptive approaches centered on transmitting information to achieve behavioral change still predominate.

With this concern in mind, the aim established for this paper was to present a brief critical review of the international literature, with emphasis on the last two decades (1985-2005), in which comprehension of the main trends in knowledge production within education for type 2 diabetes mellitus self-care and self-management would be sought. The bibliographic search was conducted in the databases of Medline and Latin American and Caribbean Literature on Health Sciences (Lilacs).

The text has been structured such that it outlines the panorama of knowledge production aimed at education and communication for type 2 diabetes mellitus self-care and self-management. It seeks, especially, to highlight some questions that we deem essential: the inappropriateness of the traditional approach of obedience to/compliance with treatment and transmission of information/knowledge for self-care, given the complexity involved in diabetes care; and the contributions that the social sciences have made to the study of chronic diseases in general and to diabetes in particular, as a possibility for overcoming the limitations of an approach at the limits of biomedicine. Finally, it seeks to pick up possible movements towards excelling and innovating within the strategies for supporting diabetes self-care, among which the strategy of patient empowerment can be highlighted.

\section{Complexity of type 2 diabetes mellitus care: criticism of the traditional focus on obedience/compliance and transmission of information for its management}

Diabetes mellitus is a disease characterized notably by dysfunction of glucose metabolism. Hyperglycemia associated with insulin deficiency (total, partial or relative, when there is insulin resistance) is the element common to all forms of the disease. The two forms that are most widespread are type 1 (which generally but not always affects children and adolescents) and type 2 (which generally develops after the age of 40 years). Type 2 accounts for around $90 \%$ of diabetes cases. The prevalence of type 2 diabetes has increased significantly in many countries around the world because of aging of the population, increasing average weight and sedentarism. This is a consequence of the patterns of life in large cities, among other conditioning factors (Scherwin, 2001). A multicenter study on the prevalence of diabetes mellitus in Brazil (Ministério da Saúde, 1992) showed a rate of $7.6 \%$ among the population aged 30 to 69 years. This would represent more than five million individuals with the disease, among whom more than half would be unaware of their condition. There are also indications that the prevalence in Brazil may be increasing, just as it is in other developing countries (Sartorelli, Franco, 2003). 
In the light of the evidence available, it is almost unanimously believed that there is a direct relationship between prolonged exposure to high blood glucose levels and the chronic complications (both microvascular and macrovascular) of diabetes. Likewise, it is believed that blood glucose control (keeping it as close to normal levels as possible) has a role in possibly preventing or delaying the development of these complications (UKPDS, 1998; The DCCT Research Group, 1993).

The belief that the better the blood glucose control is, the lower the risk of complications will be, in association with the availability of instruments for home monitoring of blood glucose levels and new therapeutic resources, has led to clinical emphasis on strict control over blood glucose levels (Olefsky, 2001), i.e. to keep them as close as possible to normal values. This has led healthcare professionals, especially physicians, to direct their clinical practices predominantly towards blood glucose control. Nevertheless, despite the evidence presented regarding the positive relationship between better blood glucose control and lower risk of complications, many studies including some with a more clinical orientation have reported enormous difficulty in attaining rigorous blood glucose control within day-to-day self-management (Frewer, Salter, Lambert, 2001; Wolpert, Anderson, 2001). The problem is such that it is often taken by healthcare professionals and even by researchers to be one of non-observance of what was prescribed. In other words, it is taken to be patients' disregard for the prescription and medical recommendations (Estupinán, Anderson, 1999). On other occasions, such nonobservance is taken to be due to patients' incompetence and irresponsibility (Roter, Stashefsky-Margalit, Rudd, 2001). This is therefore the traditional perspective of obeying the physician's instructions. The expression "obeying the physician" provides a good representation of the dominant negative sense of the term "compliance", i.e. yielding to other people. Within healthcare, compliance is generally defined as: "the extent to which a person's behavior in terms of taking medication, following diets, or executing lifestyle changes coincides with medical or health advice" (Vermeire et al., 2001, p.332).

The increasingly frequent criticisms of this notion of obeying the physician have pointed out its negative nature, especially its connotation that the patient should submit to objectives that are defined by exclusively clinical criteria and to orders from physicians. Such criticism is made in the light of the complexity of the dimensions involved in caring for chronic diseases. To achieve control over such diseases, heavy patient involvement is required. In short, the major absentee within the traditional view is an essential participant: the other side relative to medical knowledge, i.e. the perspective and experience of the person experiencing the disease (Vermeire et al., 2001; Lutfey, Wishner, 1999). This separation of the other party makes it possible for professionals to establish a moral judgement regarding non-obedience (non-compliance) and thus to label such patients as difficult or unsuitable. In this respect, in Brazilian healthcare services, the use of certain pejorative expressions of regional nature to refer to such patients can be noted.

For all these reasons, it has been proposed over the last 15 years that the use of this notion of obeying the physician (compliance) should be definitively abandoned. This challenge will not be easily achieved, given the widespread use of compliance in Medicine, as well expressed through the volume of papers published on this topic every year ${ }^{4}$.

As an alternative to the notion of obedience, despite a certain closeness to it, the concept of adherence has been put forward. The idea here is that even if it does not work as a strategic passage from a vertical relationship to another that is constructed based on cooperation and partnership between professionals and 
patients, it will at least disrupt the strong dominance of the notion of obedience in the medical-therapeutic vocabulary (Vermeire et al., 2001; Wishner, Lutfey, 2000; Lutfey, Wishner, 1999). This effort marks out a difference, albeit subtle, within the gradient of power and autonomy that is present in the professionalpatient relationship. Through this, it is sought to reduce the expression of medical power and patient submission and to move from "obedience to" the physician to "acceptance of" the treatment. However, this recommendation has been criticized because it takes the understanding that the notion of adherence would also continue to reinforce patients' submissive behavioral role, as if this were the only question involved in this complex, dynamic and multidimensional process (Glasgow, Anderson, 1999).

"Diabetes self-management education" has become recognized over the last few decades as essential for diabetes patients to achieve positive results from self-care. With this recognition, interest in and concern about the possible relationships between patients' knowledge, their control practices and the results thus attained and measured using different laboratory parameters (such as blood glucose and glycated hemoglobin) have increased. Many studies have sought to investigate the relationships between these spheres (knowledge, control practices and results). However, analysis on these studies through systematic reviews and meta-analyses has shown serious methodological problems, both in the instruments used and in the interpretation of the results. This has been especially true in relation to studies that sought direct linear linkages between these dimensions (Coates, Boore, 1996). Over recent decades, 70\% of what has been published on education and diabetes has been limited to application of before and after tests to measure the level of knowledge among groups of patients (Brown, 1999). This not only well emphasizes the fragility of what has been produced but also, especially, exposes the assumptions underlying these studies. They took the problem of non-adherence or lack of self-management to be probably due to patients' lack of knowledge of the measures needed for them to achieve "good blood glucose control" and thus to benefit from a lower risk of developing complications. These studies sought to measure the results obtained from supplying the patients with "deposits" of information, in terms of the "stock" available to them before and after the educational intervention that was implemented 5 .

When better-structured studies sought to investigate whether the guidance supplied by professionals would result in effective control, they demonstrated that interventions that expanded patients' knowledge about the disease and its care did not produce any results regarding blood glucose parameters. This draws attention to the complexity of connecting from knowledge to care practices (Bloomgarden, 1987; Coates, Boore, 1996).

Recognition of these problems does not mean disregarding the value of the technical-scientific knowledge available and the possibility that professionals could share this knowledge with their patients, for them to be able to make informed choices in the light of their problems and needs. On the other hand, it indicates the insufficiency and fragility of snippets of information for enabling patients to grasp the whole picture. This may simply be because such knowledge passed on by physicians to their patients will never be "experience gained" by the patients themselves but, rather, knowledge from "transmitted experience". These patients would have to diligently receive, memorize and repeat, as observed well by Paulo Freire (1975) in relation to traditional teacher-student dynamics. As already commented, in relation to the notion of adherence, the great absentees in this "education for diabetes control" are again patients: the

\footnotetext{
${ }^{5}$ The expressions

"deposits" and

"stock" are used here in the sense taken by Paulo Freire (1975) in his conceptual criticism of traditional education (or "banking education", as he called it).
} 
ones who are experiencing the problem. Moreover, it has to be mentioned that such experience often occurs within contexts of conflict between the recommendations, patients' needs and desires and the existence of social or cultural mechanisms that might at least balance the dynamics between the preceding terms.

From the perspectives of obedience/adherence and knowledge/practice relationships that are more linear, the knowledge produced has been insufficient to overcome the perception of failure felt by professionals and patients when faced with the limited results achieved and the difficulties that have been described. Furthermore, and of no less concern, there are the ethical repercussions, given the devaluation of the subjects, their substantive contexts and their knowledge.

However, even though a significant number of studies are still looking into these questions, a recent reorientation within this field can be discerned. There are increasing efforts towards placing value on individuals' own experiences and notions about diabetes, in order to gain a better grasp of the richness and subtlety of the questions involved in self-care (Anderson, Robins, 1998). Faced with these challenges, many investigators have sought methodological resources that would allow them to better pick up the nuances and singularities of these subjects, and to better understand the discourse produced. These new trials have been constructed through incorporation of different types of qualitative research and a closer approach to different disciplines within the social sciences, in view of the aim of finding out about individuals and the experiences that they develop as subjects and patients.

If on the one hand, turning towards the other party in the educational process has been due to contributions from critical pedagogy, such as that of Paulo Freire; on the other hand, this approach that values patients' subjective perspectives is the result from important contributions made by the social sciences, especially anthropology and sociology, in studies on chronic diseases in general and on diabetes in particular.

Study of chronic diseases: from biomedicine to the social sciences.

When an acute health complaint is experienced, even if only a simple cold or the flu and of short duration, it gives rise to physical and mental feelings of illness. These often lead people to interrupt part of their activities or stop working for a few days, while expecting understanding and sympathy from others. These brief experiences contrast with the experiences of individuals with chronic diseases that, by definition, are long-duration conditions or permanent features in their lives and therefore have different repercussions (Nettleton, 1995).

One phenomenon that has already been studied within both the social sciences and psychology is the impact on the course of individuals' lives when they start to present a chronic disease: a time when there may be a "biographical disruption" (Bury, 1982), i.e. a break in the way that their lives had been progressing until that time (Canguilhem, 1990). The manifestation of chronic disease within individuals' social lives can be examined from at least two perspectives: its consequences on day-today routines and its significance for such individuals and for society and the interrelations between these (Bury, 1991). This opens up the possibility of recognizing that the health-disease phenomenon may have cultural pluralism of expression within different social settings (Laplantine, 1991).

The transformations in the day-to-day lives of individuals with chronic illnesses go beyond the dimensions that more directly relate to the discomfort of their symptoms and body feelings. Thus, for some individuals, for example, what makes them worry is the lack of symptoms, expressed as "silent diabetes", from which complications appear without warning. If "health is life in the silence of the organs", as put forward by Leriche (apud Canguilhem, 1990, p.67), then a situation in which an individual is shown by his physician to have hyperglycemia, even without manifestation in the body, transforms the "silent diabetes" into discomfort for the patient and brings it closer to this same author's notion of disease as something that disturbs the normal course of people's lives (p. 67).

The manifestations of chronic diseases will also be perceived, like in cases of diabetes, through the burden consequent to the requirements for controlling it, which the individual with the disease will have to shoulder. Although professionals prescribe medications, and recommend and guide care measures for patients, it is up to patients to organize these measures within their everyday lives. This requires enormous adaptive effort by patients, for them to be able to deal with these 
recommendations within daily routines that have already been structured through their established habits of family and social relationships. In this situation, individuals with chronic diseases will be faced with new problems that will require them to develop skills for dealing with a wide range of activities that have been foreseen through medical (clinical) knowledge. The factors involved include medication, diet, monitoring of capillary blood glucose, physical exercise, foot care, etc. Furthermore, there may be other such activities not foreseen through this clinical knowledge, especially with regard to possible situations that cause difficulty in achieving such control, in view of patients' sociocultural contexts, as mentioned earlier.

Although patients generally know about (and even fear) the chronic complications of diabetes, many of them will have enormous difficulty in following these recommendations, in view of the habits, choices and priorities that they have already instituted within their lives. It is not unusual for patients to say that they are ashamed of or to blame for their disease and their difficulties in undertaking their self-care, especially in relation to a condition that demands so many lifestyle changes. According to the field of studies on "social representations", the care practices adopted by individuals are an expression of the meanings produced in relation to their identities and self-esteem, and in relation to their own ideas about their state of health and the individual manifestation of their disease. Nonetheless, such expressions are rooted in their sociocultural context, as a semantic network relating to becoming ill and being healthy (Adam, Herlich, 2001). The explanatory framework of "representations" provides theoretical and methodological backing that has made it possible to broaden the understanding of many dimensions of this process of configuration of senses and conformation of this network of meanings, through which individuals will acknowledge that they present a chronic disease. Hence, this is an important advance in how the question of knowledge is approached, compared with the dominant approaches within medicine, especially as applied to patient education (obedience/ adherence and transmission of information), which was dealt with in the preceding section.

The limitations of biomedicine are shown up in the light of the need to grasp the complexity of becoming ill and living with a chronic disease. This results from some of the characteristics of biomedicine, such as: the body-mind dualism of medicine; the mechanistic view of the human body; the excessive value placed on "technological tools"; the notion of disease centered on its biological expression, thereby neglecting its social and psychological dimension ("biologicism"); and finally, the accentuation of this reductionism through the dominance of unicausality as the logic for etiological explanations of diseases (Nettleton, 1995). The representation of the disease elaborated through subjective experiences of illness does not fit in with the notion of disease "as scientifically observed and objectified" through biomedicine. Practices within biomedicine have the effect of reducing illness to disease. Thus, it is precisely "within this inadequacy that psycho and sociomedical interpretations of disease are set up" (Laplantine, 1991, p.17). Nevertheless, this field of tension is also a space for clinical medicine (the meeting place between the physician, i.e. the provider of care, and the patient, i.e. the one who is suffering), since clinical medicine puts physicians in contact with complete and substantive individuals and not with their organs and functions (Canguilhem, 1990, p.65).

As Bury (1991) highlighted, biomedicine is not the only approach that is inadequate for recognizing the multidimensional nature and complexity of this universe. Other approaches may also be inadequate, including the field of social sciences, if they latch onto restrictive explanatory models that fail to consider the diversity and richness of individual experiences of facing up to these problems.

These are just some of the complex questions relating to the impact of chronic diseases such as diabetes on day-to-day life and to the difficulties of self-care. Additionally, there are the difficulties in capturing the essence of these issues that have been faced within different focuses.

\section{Current trends within education and communication for self-care and self- management of type 2 diabetes}

Among the diversity of recent movements that have sought to challenge the limitations of the biomedical care model, one that has achieved great dissemination in the international literature, and especially in the English-language literature, can be highlighted: patient-centered medicine. 
Under this name, there are many proposals for reorienting care practices, and especially medical care practices. With prominent influence from psychology and the social sciences (anthropology of health, medical anthropology and sociology of disease and medicine), these proposals have the common element of a perception of the limitations of the traditional medical model. Within this heterogeneity, concepts and formulations going from the work of Balint in the 1950s to the most recent and broadest notions of shared decision-making can be identified. While Balint proposed that "patients should be understood in their entirety as human beings", the most recent proposals have added to this through a biopsychosocial approach to patients' problems. They have placed value on patients' experiences and have sought to establish professional-patient relationships in which judgement and responsibility is shared with greater patient autonomy, such that an alliance between physician and patient is constructed around the treatment (Bower, Mead, 2000).

Within the scope of diabetes care, this focus has stimulated the professionals and researchers to seek a new basis for the work of attention and education aimed at self-care and self-management.

From this perspective, Wolpert e Anderson (2001) recognized that if strict blood glucose control is taken to be the main care objective, this ends up transmitting to patients (albeit implicitly) the idea that good control consists of a type of control in which flexibility and the possibility of making choices within diabetes care are relinquished. This means letting life be controlled by the disease, i.e. the diabetes. This is because the focus of such patients' care and consequently the focus of their lives will be organized around a routine of measuring blood glucose levels, insulin doses and numbers of administrations per day, etc. In seeking to surmount this focus, these authors recommended that the guidance given to patients should include recognition of the tools available for self-management as means for expanding patients' freedom and autonomy within their daily lives. The implicit message is that good control over diabetes can be achieved without letting it dominate life. Thus, self-care and self-management should be performed flexibly, such that patients can adapt the treatment to the demands of their daily routines.

These proposals have been backed by different investigations of qualitative nature that were designed to recognize the experiences of people living with diabetes. Among these studies, the one developed by Campbell et al. (2003) with a certain degree of conceptual innovation can be highlighted. This sought to integrate different qualitative studies into an overall picture, through meta-ethnography. This investigation revealed new points through the synthesis produced, such as the importance of "strategic non-compliance" adopted by some individuals, who do not blindly adhere to medical advice in their daily lives but, instead, they thoughtfully and selectively apply it. Through this, they seek to achieve a balance between the demands of diabetes control and the way they want to lead their lives, even by means of "strategic cheating". The study showed that such individuals had feelings of confidence about how they were implementing diabetes care, with less guilt, greater acceptance of their condition and better blood glucose control.

In the following, a panorama of the production of knowledge relating to education for diabetes self-care and self-management is presented. The aim was to pick up these recently delineated trends better, and review studies and meta-analyses were useful in this respect. From this examination of the literature, a more general view was then sought through examination of experiences that were more "patient-centered" and that explicitly or implicitly took up an ethical stance aimed at ensuring that individuals participated more actively in their care, with greater respect for their autonomy.

Slight signs of this trend can already be discerned from the adoption of the terms "self-care" and "self-management". These new terms were introduced through initiatives within the field of "diabetes self-management education", as it has been more widely named (Roter, StashefskyMargalit, Rudd, 2001).

A review by Brown (1999), on intervention studies relating to "diabetes self-management education" covering the period from 1980 to 1998, recognized a change in focus from one decade to the next. While studies aimed at measuring patients' knowledge of the disease and its control before and after an educational intervention predominated in the first decade (1980s), the next decade showed greater production of interventions that, in addition to this "focus on knowledge", presented strategies aimed at supporting effective attainment of self-care. The author called them "behavioral 
strategies" and they involved empowerment, "support groups", "problem-solving" (Brown, 1999, p.56) and, furthermore, "autonomy-supportive motivation" (Williams, Freedman, Deci, 1998). Some brief comments on these strategies need to be made here, with the exception of empowerment, which is dealt with more fully later on.

"Self-help group" or "support groups" grew significantly in North American and European countries in the 1960s. They involved mutual assistance practices that were organized and directed by individuals who shared the same health problem, such as alcoholism, cancer, diabetes etc. (Roter, 2001; Dean, 1986). In Brazil, the most notable expansion of such groups, without links to healthcare institutions, initially occurred through associations for alcohol-dependent individuals. Today, this strategy is widely present in primary healthcare services, given the expansion of the Family Health Program in this country. It includes so-called "diabetes groups" or "hypertension groups", which are organized from different educational perspectives with new types of self-help group. With the spread of new communication technologies like the internet, experiences of these new groups, i.e. "self-help online communities" have been multiplying around the world (Ziebland, 2004).

"Problem-solving" and "autonomy-supportive motivation" strategies are applications coming from the field of cognitive psychology. In seeking to expand the skills required for self-care, the former aims at amplifying the "problem-solving skills". Through these, patients become able to control the difficulties regarding care that they face in their daily routine. Four components of problem-solving relating to disease self-management have been identified, which may be manifested positively or negatively: problem-solving skills; guidance for problem-solving; specific knowledge of the disease; and capacity to use acquired experience for solving future problems (Hill-Briggs, 2003; Hill-Briggs et al., 2003).

In turn, "autonomy-supportive motivation" is based on the theory of human motivation, in which two type of motivation are recognized: autonomous and controlled. Autonomous motivation is believed to be the only type that is capable of ensuring rigorous blood glucose control over long periods, as required for diabetes (Williams, Freedman, Deci, 1998).

Other studies have showed that maintaining the trend towards incorporating the above practices is aimed more towards strengthening the role of patients in their care, with greater emphasis on activities to be performed at home, and also greater use of computers as support for glucose control, among other matters. There are several studies that have presented evaluations on the use of software or websites for supporting patients in their self-care (Ralston, 2004; Boisen et al., 2003).

In a review (Fain et al., 1999) covering the period from 1985 to 1999 that had greater interest in characterizing the theoretical-methodological reference point adopted in the literature regarding "diabetes education", it was found that only $6 \%$ of the studies made reference to the theoretical orientation adopted. Moreover, in most of these, there was disconnection between the theoretical framework and the concepts used in the study. Another limitation observed related to the short time that was set in most studies between the intervention and the subsequent measurement of the possible results (three months). A longer time would be desirable, in order to find out whether the results obtained would be sustained over a longer period. However, different authors (Loveman, 2003; Fain et al., 1999; Glasgow, 1999) highlighted important limitations in their results, insofar as their measurements were limited to laboratory parameters for blood glucose control, while disregarding other relevant dimensions of clinical and psychosocial nature.

In addition to the problems cited, some authors (Brown, 1999; Fain et al., 1999) have recognized a question that seems to be very important: "in the end, what in fact are the educational practices for diabetes?" This doubt arises because the descriptions of the interventions are very scanty in the published articles. Thus, the possibility of analyzing and perhaps reproducing the results, and particularly the possibility of examining different experiences as support for diabetes care practices, is impaired.

From all of the above, despite the large number of limitations relating to various studies, including the precarious basis of many of them, it can be said that there is a certain tendency for the proposals to turn towards the patients with diabetes. In addition, the strategy established around the notion of empowerment within each of these studies needs to be examined. This is because of the prominence given to empowerment by different authors, regarding its innovative nature in relation to traditional education for diabetes control. 


\section{“Empowerment" as a support strategy for diabetes self-care}

Empowerment was introduced within "diabetes self-care education", at the start of the 1990s, inspired by the contributions of Paulo Freire that were applied to healthcare education (Wallerstein, Bernstein, 1988) and community psychology (Roter, Stashefsky-Margalit, Rudd, 2001; Feste, Anderson, 1995). This concept is today used in different fields with different meanings. Within healthcare, great value has been placed on it by the healthcare promotion movement, and it has become one of the seven principles of healthcare promotion, (Sícoli, Nascimento, 2003; Anderson, 1996) even though its use is highly polemical (Carvalho, 2004).

Within diabetes self-care education, empowerment has been defined as "the discovery and development of one's inherent capacity to be responsible for one's own life" (Funnell, Anderson, 2003, p.454). In the sense of placing value both on autonomy and on individual responsibility, with emphasis on the latter, this concept comes close to what has been conceptualized as "psychological empowerment": the "feeling [experienced by individuals] of greater control over their own lives" (Carvalho, 2004, p. 1090).

This process will be successful if it results in an "empowered" individual: one with "sufficient knowledge to make rational decisions, sufficient control and resources to implement their decisions, and sufficient experience to evaluate the effectiveness of those choices" (Funnell, Anderson, 2003, p.454). In this definition, overvaluation of the more rational dimensions of decision-making and control within the self-care process is evident.

The idea underlying this notion is that, with support from healthcare professionals, individuals can develop their capacities and skills to recognize their own needs and solve their own problems, through mobilizing the resources to have control over their lives (Anderson, 1996). The criticism that has been made regarding this individualist focus is that it minimizes (or ignores) the constraints imposed by the social structure (Carvalho, 2004; Anderson, 1996) and the vulnerability resulting from this, including in relation to the quality and availability of the care services, i.e. programmatic vulnerability (Ayres et al., 1999). It needs to be noted that this individualistic ideology has been strengthened within the international situation of controlling fiscal deficits and reducing the expenditures on social policies. This has influenced the emergence of new public policies of autonomist nature that make a "broad appeal to mutual help and solidarity among the population, so that it can, as far as possible, solve their own health problems" (Nogueira, 2003, p.17).

It should be noted, in this proposal for empowerment, that patients' experiences are given great value since, as its proponents affirm: while "health professionals are experts on diabetes care, patients are the experts on their own lives" (Funnell, Anderson, 2004, p.124). Within this perspective, the possibility highlighted is that diabetes care

becomes a collaboration between equals; professionals bring knowledge and expertise about diabetes and its treatment, and patients bring expertise on their lives and what will work for them. To effectively implement this approach, patients need education designed to promote informed decision-making, and providers need to practice in ways that support patient efforts to become effective self-managers. (Funnell, Anderson, 2004, p.124)

Therefore, the value placed on experience attests to "the ability of participants to determine an approach to diabetes self-management that will work for them", and provides recognition for "the innate capacity of patients to identify and learn to solve their own problems", insofar as "the person with diabetes is responsible for and in control of the daily self-management of diabetes" (Funnell et al., 2005, p.56).

In the above sense and in a complementary manner, looking at this proposition now from a more practical perspective, the example of the program of the Michigan Diabetes Research and Training Center from the University of Michigan in the United States was chosen as a set of experiences to be examined. The aim was to investigate how empowerment was put into operation within the scope of a particular and substantive experience of diabetes self-care education. 
The intervention and research program of the University of Michigan was developed through activities among small groups of patients in six weekly two-hour sessions, with questionnaires applied to make a variety of measurements. Among the topics dealt with in these meetings were the following: wellbeing, which was worked on in such a way as to encourage people to identify their values, needs and objectives; self-image, which was explored in the light of its power to influence behavior and attitudes; problem-solving, as a process developed in stages to overcome day-to-day questions; and patient support. These were examined regarding their significance for individuals: who they could count on; who they liked to receive support from; and what they needed for this. Motivation, adaptability and stress control were also worked on (Feste, Anderson, 1995).

Three tools were used to develop the strategy of empowerment: valuing questioning, storytelling and working on behavioral language (Feste, Anderson, 1995). As to the first two dimensions, some proximity to the process of "reflective action" of Paulo Freire can be identified, insofar as questioning seeks to induce expression of and reflection about one's own daily experience. Likewise, storytelling is a tool that aims to facilitate the process of self-discovery regarding values and beliefs (Funnell, Anderson, 2004; Feste, Anderson, 1995). Thus, these tools open the possibility of reflective action regarding the narrative of experience.

From examination of two papers evaluating the University of Michigan program, with a ten-year interval between them (Funnell et al., 2005; Anderson et al., 1995), it can also be seen that, on the second occasion, although the basic structure of the group activities was preserved, the researchers had ensured freer and more active participation by the patients. The sessions were guided by questions presented by the participants. Thus, the content of the group sessions on the second occasion was better connected with the questions and demands raised by the participants. They were also encouraged, at the end of each meeting, to present their aims and the steps that they planned to take within their self-management (Funnell et al., 2005).

This proposal for empowerment, despite the bias of the "individualistic ideology", can be recognized as adhering to a more dialogic form of education. This is not only because it incorporates certain elements of "problem-setting pedagogy" from the experiences of support groups and selfhelp groups of interactive nature, but also because of the ethical stance of greater respect for the moral and cognitive autonomy of the other party. The effect produced is a communication scenario of dialogic and nonlinear nature. In this process, it can be said that healthcare education encompassess communication, thereby forming a sphere of healthcare education/communication as the practice for relationships between healthcare professionals and patients.

\section{Final considerations}

The approach taken towards this topic of education for diabetes self-care and self-management was also shown to be useful for picking up the more general dynamics of the innovations that have been sought, especially in relation to chronic diseases.

In this respect, it was possible to recognize a certain inflection within this field of practices and research, which has traditionally been guided by biomedicine. This was recognized thanks to the contributions that the social sciences have provided to studies on chronic diseases in general and diabetes in particular.

A certain degree of reorientation in the international scientific production directed towards diabetes self-care education that has been published over the last two decades can now be identified. As seen, there is a recognition that education centered on transmission of information is insufficient to ensure effective self-care and self-management, thereby reinforcing the perception of the complexity involved in the relationship between knowledge and care practices. In addition, there is the strengthening of an ethical stance that is more oriented towards patients with diabetes, and this is expressed through criticism of the perspective of adherence to treatment, either because of its nature centered on patients' behavior, or because of its conformity with a predominantly medical view of the problems of self-care. In this respect, the influence of critical pedagogy, such as that of Paulo Freire, together with 
the backing from the social sciences, strengthens the reorientation of researchers' viewpoints towards incorporation of the subjects of care into care practices.

Among the new approaches proposed for diabetes self-care education, guided by the perspective of "patient-centered medicine", the strategy of "empowerment" seems to be the one most influenced by the formulations criticized, as mentioned above.

Even though very many advances have been recognized with regard to developing strategies that are more dialogic, such as empowerment, many questions still present challenges relating to organizing healthcare education practices guided from the perspective of placing value on subject autonomy, for the reasons laid out earlier.

Within the inexhaustible field of production of problems and possibilities, there can still be discussion about how to move forward with regard to recognizing the difficulties experienced by subjects in their everyday routines, as exemplified in the epigraph that opens this article. Likewise, there can be discussion about how to recognize the knowledge produced within day-to-day self-care ("knowledge through experience"), which shapes the competence produced within the continual process of overcoming obstacles and making choices about how to lead one's life. The extent to which these problems and knowledge can be applied in constructing care practices that place value on ties of solidarity and mutual help between patients can also be questioned.

Furthermore, it has to be borne in mind that, within the gradation of possible focus going from healthcare professionals (physicians) to patients, there are other approaches within a more immediately relational perspective, which could be called "meeting-centered". Some elaborations that have not yet been fully developed are very promising in this respect. Among these are "expanded clinical medicine" (Campos, 2003), "welcoming as a conversation network" (Teixeira, 2003) and "narrative-based medicine" (Launer, 2002). Nevertheless, as already stated, these are formulations that are still generic and they are only mentioned here because of the potential of this focus and because of the innovation that they may represent with regard to the topic of health education/communication and, in particular, with regard to diabetes self-care.

\section{Collaborators}

Antonio Pithon Cyrino was responsible for reviewing the literature and preparing the text; Lilia Blima Schraiber and Ricardo Rodrigues Teixeira collaborated in different aspects of constructing and reviewing the text.

\section{References}

ADAM, P.; HERLICH, C. Sociologia da doença e da Medicina. Bauru: Edusc, 2001.

ANDERSON, J.M. Empowering patients: issues and strategies. Soc. Sci. Med., v.43, n.5, p.697-705, 1996.

ANDERSON, R.M. et al. Patient empowerment: results of a randomized controlled trial. Diabetes Care, v.18, n.7, p.943-9, 1995.

ANDERSON, R.M.; ROBINS, L. How do we know? Reflections on qualitative research in diabetes. Diabetes Care, v.21, n.9, p.1387-8, 1998.

AYRES, J.R.C.M. et al. Vulnerabilidade e prevenção em tempos de Aids. In: BARBOSA, R.M.; PARKER, R.G. (Orgs.). Sexualidades pelo avesso: direitos, identidade e poder. São Paulo: Editora 34, 1999. p.49-72. 
BLOOMGARDEN, Z.T. et al. Randomized, controlled trial of diabetic patient education: improved knowledge without improved metabolic status. Diabetes Care, v.10, n.3, p.263-72, 1987.

BOISEN, E. et al. Copability, coping, and learning as focal concepts in the evaluation of computerised diabetes disease management. Int. J. Med. Inform., v.70, n.2-3, p.353-63, 2003.

BOWER, P.; MEAD, N. Patient-centredness: a conceptual framework and review of the empirical literature. Soc. Sci. Med., v.51, n.7, p.1087-1110, 2000.

BRASIL. Ministério da Saúde. Estudo multicêntrico sobre a prevalência do diabetes mellitus no Brasil. Inf. Epidemiol. SUS, v.1, n.3, p.47-73, 1992.

BROWN, S.A. Interventions to promote diabetes self-management: state of the science. Diabetes Educ., v.25, supl.6, p.52-61, 1999.

BURY, M. The sociology of chronic illness: a review of research and prospects. Sociol. Health IIIn., v.13, n.4, p.451-68, 1991. 1982. Chronic illness as biographical disruption. Sociol. Health Illn., v.4, n.2, p.167-82,

CAMPBELL, R. et al. Evaluating meta-ethnography: a synthesis of qualitative research on lay experiences of diabetes and diabetes care. Soc. Sci. Med., v.56, n.4, p.671-84, 2003.

CAMPOS, G.W.S. Saúde paidéia. São Paulo: Hucitec, 2003.

CANGUILHEM, G. O normal e o patológico. 3.ed. Rio de Janeiro: Forense Universitária, 1990.

CARVALHO, S.R. Os múltiplos sentidos da categoria "empowerment" no projeto de promoção à Saúde. Cad. Saude Publica, v.20, n.4, p.1088-95, 2004.

COATES, V.E.; BOORE, J.R.P. Knowledge and diabetes self-management. Patient Educ. Couns., v.29, n.1, p.99-108, 1996.

CYRINO, A.P.P. Entre a ciência e a experiência: uma cartografia do autocuidado no diabetes. São Paulo: Editora Unesp, 2009. [no prelo]

DEAN, K. Lay care in illness. Soc. Sci. Med., v.22, n.2, p.275-84, 1986.

ESTUPINÁN, F.V.; ANDERSON, R.M. Activación y motivación del paciente diabético. In: ISLAS ANDRADE, S.; LIFSHITZ GUINZBERG, A. (Orgs.). Diabetes Mellitus. 2.ed. México: McGraw-Hill Interamericana, 1999. p.438-44.

FAIN, J.A. et al: Diabetes patient education research: an integrative literature review. Diabetes Educ., v.25, supl.6, p.7-15, 1999.

FESTE, C.; ANDERSON, R.M. Empowerment: from philosophy to practice. Patient. Educ. Couns., v.26, n.1-3, p.139-44, 1995.

FREIRE, P. Pedagogia do oprimido. 3.ed. Rio de Janeiro: Paz e Terra, 1975.

FREWER, L.J.; SALTER, B.; LAMBERT, N. Understanding patients' preferences for treatment: the need for innovative methodologies. Qual. Health Care, v.10, supl.1, p.50-4, 2001.

FUNNELL, M.M. et al. Implementing an empowerment-based diabetes self-management education program. Diabetes Educ., v.31, n.1, p.53-61, 2005.

FUNNELL, M.M.; ANDERSON, R.M. Empowerment and self-management of diabetes. Clin. Diabetes, v.22, n.3, p.123-7, 2004.

Patient empowerment: a look back, a look ahead. Diabetes Educ., v.29, n.3, p.454-62, 2003. 
GLASGOW, R.E.; ANDERSON, R.M. In diabetes care, moving from compliance to adherence is not enough: something entirely different is needed (Letter). Diabetes Care, v.22, n.12, p.2090-1, 1999.

GLASGOW, R.E. Outcomes of and for diabetes education research. Diabetes Educ., v.25, n. 6 suppl, p.74-88, 1999

HERBERT, C.P.; VISSER, A. Improving self-management in patients with diabetes: knowledge is not enough. Patient Educ. Couns., v.29, n.1, p.1-31, 1996.

HILL-BRIGGS, F. Problem solving in diabetes self-management: a model of chronic illness self-management behavior. Ann. Behav. Med., v.25, n.3, p.182-93, 2003.

HILL-BRIGGS, F. et al. Qualitative study of problem solving and diabetes control in type 2 diabetes self-management. Diabetes Educ., v.29, n.6, p.1018-28, 2003.

LAPLANTINE, F. Antropologia da doença. São Paulo: Martins Fontes, 1991.

LAUNER, J. Narrative-based primary care. Oxon: Radcliffe Medical Press, 2002.

LOVEMAN, E. et al. The clinical and cost effectiveness of patient education models for diabetes: a systematic review and economic evaluation. Health Technol. Assess., v.7, n.22, p.1-190, 2003.

LUTFEY, K.E.; WISHNER, W.J. Beyond "compliance" is "adherence". Diabetes Care, v.22, n.4, p.635-9, 1999.

NETTLETON, S. The sociology of health and illness. Cambridge: Polity Press, 1995.

NOGUEIRA, R.P. A saúde pelo avesso. Natal: Seminare, 2003.

OLEFSKY, J.M. Prospects for research in diabetes mellitus. JAMA, v.285, n.5, p.628-32, 2001.

RALSTON, J.D. et al. Patients' experience with a diabetes support programme based on an interactive electronic medical record: qualitative study. BMJ, v.328, n.7449, p.1159, 2004.

ROTER, D.L.; STASHEFSKY-MARGALIT R.; RUDD, R. Current perspectives on patient education in the US. Patient Educ. Couns, v.44, n.1, p.79-86, 2001.

SARTORELLI, D.S.; FRANCO, L.J. Tendências do diabetes mellitus no Brasil: o papel da transição nutricional. Cad. Saude Publica, v.19, supl.1, p.S29-S36, 2003.

SCHERWIN, R. Diabete melito. In: GOLDMAN, L.; BENNETT, D. (Orgs.). Cecil: tratado de medicina interna. 22.ed. Rio de Janeiro: Guanabara Koogan, v.2, p.1658-92, 2001.

SíCOLI, J.L.; NASCIMENTO, P.R. Promoção de saúde: concepções, princípios e operacionalização. Interface - Comunic., Saude, Educ., v.7, n.12, p.91-112, 2003.

SNOEK, F.J. Breaking the barriers to optimal glycaemic control - what physicians need to know from patients' perspectives. Int. J. Clin. Pract. Suppl., n.129, p.80-4, 2002.

TEIXEIRA, R.R. O acolhimento num serviço de saúde entendido como uma rede de conversações. In: PINHEIRO, R.M.; MATTOS, R.A. (Orgs.). Construção da integralidade: cotidiano, saberes e práticas em saúde. Rio de Janeiro: UERJ/IMS/Abrasco, 2003. p.89111.

The DCCT Research Group: the effect of intensive treatment of diabetes on the development and progression of long-term complications in insulin-dependent diabetes mellitus. N. Engl. J. Med., v.329, n.14, p.977-86, 1993.

UK Prospective Diabetes Study (UKPDS) Group. Intensive blood-glucose control with sulphonylureas or insulin compared with conventional treatment and risk of complications in patients with type 2 diabetes (UKPDS 33). Lancet, v.352, n.9131, p.837-53, 1998.

VERMEIRE, E. et al. Patient adherence to treatment: three decades of research: a comprehensive review. J. Clin. Pharm. Ther., v.26, n.5, p.331-42, 2001. 
WALLERSTEIN, N.; BERNSTEIN, E. Empowerment education: Freire's ideas adapted to health education. Health Educ. Q., v.15, n.4, p.379-94, 1988.

WILLIAMS, G.C.; FREEDMAN, Z.R.; DECI, E.L. Supporting autonomy to motivate patients with diabetes for glucose control. Diabetes Care, v.21, n.10, p.1644-51, 1998.

WISHNER, W.J.; LUTFEY, K.E. Response to Glasgow and Anderson (Letter). Diabetes Care, v.23, n.7, p.1034-5, 2000.

WOLPERT, H.A.; ANDERSON, B.J. Management of diabetes: are doctors framing the benefits from the wrong perspective? BMJ, v.323, n.7319, p.994-6, 2001.

ZIEBLAND, S. The importance of being expert: the quest for cancer information on the internet. Soc. Sci. Med., v.59, n.9, p.1783-93, 2004.

CYRINO, A.P.; SCHRAIBER, L.B.; TEIXEIRA, R.R. La Educación para el auto-cuidado en la diabetes "mellitus" tipo 2: de la adhesión al "empoderamento". Interface - Comunic., Saude, Educ., v.13, n.30, p.93-106, jul./set. 2009.

En revisión crítica de la literatura sobre la educación para el auto-cuidado y auto-control en la diabetes, se trata de apuntar la inadecuación de los planteamientos tradicionales de adherencia al tratamiento y de la transmisión de informaciones ante la complejidad del auto-cuidado en condiciones de cronicidad. Se explora la influencia de las Ciencias Sociales sobre el campo de estudio de las enfermedades crónico-degenerativas en general y de la diabetes en particular. En tal perspectiva se puede reconocer una incorporación de los campos disciplinarios de la Antropología y Sociología en pesquisas más orientadas hacia el individuo en su condición de portador y la experiencia que desarrolla en este proceso. Hay cierta inflexión más reciente en el campo de pesquisas en educación en salud en la diabetes con la introducción de estrategias que tratan de valorizar la experiencia y la autonomía de los pacientes como sujetos de su cuidado. En este artículo se discute la estrategia del "empoderamento" en la educación para el auto-cuidado y auto-control en la diabetes, como una modalidad de práctica de naturaleza más dialógica y de mayor respeto a la autonomía moral y cognitiva del portador.

Palabras clave: Diabetes mellitus tipo 2. Auto-cuidado. Educación en salud/métodos. Enfermedades crónico-degenerativas. Ciencias sociales. 